\title{
Analisis Diskors Kurikulum dan Pedagogi pada Mata Kuliah Bahasa Inggris dalam Konteks Interdisipliner di Politeknik Negeri Jember
}

\author{
Adriadi Novawan \\ Politeknik Negeri Jember
}

\begin{abstract}
Abstrak
Artikel ini melaporkan hasil studi kasus yang meneliti realita kurikulum Bahasa Inggris dalam konteks kurikulum induk yang menaunginya dan implementasinya ditingkat pedagogi. Tujuan penelitian adalah untuk mengetahui sejauh mana implementasi pedagogi telah sesuai dengan kebijakan pada kurikulum induknya. Framework yang dipergunakan khususnya menganalisa hubungan antara curriculum as written, curriculum as taught, dan curriculum as experienced. Penelitian ini dilandasi prinsip naturalistic inquiry yang mengutamakan eksplorasi terhadap realita alami tanpa modifikasi. Data dikumpulkan dengan menggunakan dokumentasi, wawancara dan focus group discussion dan dianalisa dengan menggunakan metode Immersion/Crystallisation (I/C). Hasil penelitian menunjukkan bahwa realita curriculum as written bersifat implisit dan terbuka, curriculum as taught mewakili konsep weak framing, dan curriculum as experienced cenderung mengutamakan terbentuknya self-confidence dan intrinsic motivation ketimbang pencapaian materi. Implikasi penting yang perlu diperhatikan dalam pengembangan kurikulum dan pedagogi kedepan adalah bahwa realita kuatnya weak classification pada curriculum as written dan weak framing pada curriculum as taught akan menyebabkan sulitnya standarisasi kompetensi bahasa dalam kerangka konvergen dengan mengikuti standar yang direkomendasikan.
\end{abstract}

\begin{abstract}
The article reports the results of a case study which explored the reality of English curriculum within the overarching curriculum and its implementation in the level of pedagogy. The aim was to know the extent to which the implementation of pedagogy has been coherent to the policy of the overarching curriculum. The framework used particularly was to analyze the relationship between curriculum as written, curriculum as taught, and curriculum as experienced. The research was underpinned with the principle of naturalistic inquiry that emphasises the exploration of the natural reality without modification. Data were collected by using documentation, interviews and focus group discussion, and were analized by using Immersion/Crystallisation (I/C). The results of the research shows that the reality of curriculum as written tended to be implicit and open, curriculum as taught represented the notion of weak framing, and curriculum as experienced was prone to orient itself to build self-confidence and intrinsic motivation of the students rather than the completeness of the materials. A crucial implication for future curriculum and pedagogy development will be that the high level of weak classification on curriculum as written and weak framing on curriculum as taught will result in difficulty in standardizing the English competency in a recommended convergent framework of reference.
\end{abstract}




\section{Latar Belakang}

Kurikulum nasional telah mengalami penguatan dalam hal koherensi (keterpaduan) antara kurikulum pendidikan dasar, pendidikan menengah dan pendidikan tinggi. Pada saat kurikulum pendidikan dasar dan menengah telah mengakomodasi arah perubahan kurikulum PT (Kementerian Pendidikan dan Kebudayaan, 2012), kurikulum pendidikan tinggi juga mengalami perubahan menurut konsep integrasi kompetensi kerja yang didasarkan pada Kerangka Kualifikasi Nasional Indonesia (KKNI). KKNI mengintegrasikan target luaran pada setiap jenis pendidikan baik vokasi, profesi maupun akademi (Direktorat Jenderal Pendidikan Tinggi, 2011). Hal ini menunjukkan bahwa sistem pendidikan di Indonesia telah memperhatikan kualitas relevansi dan koherensi. Kebijakan kurikulum di suatu perguruan tinggi, misalnya, juga perlu memiliki koherensi dengan implementasinya ditingkat fakultas/jurusan, program studi, dan kelas. Penting untuk disadari bahwa koherensi antara kebijakan dan implementasinya merupakan suatu realita yang perlu dikaji dan dianalisa karena dapat menunjukkan sejauh mana perencanaan dapat diimplementasikan seutuhnya. Jika tidak, maka faktor-faktor yang mempengaruhi dapat diidentifikasi dan dipelajari sebagai evidence untuk perbaikan kurikulum selanjutnya.

Sebagaimana yang dibahas dalam penelitian lain, perubahan kurikulum ditingkat kebijakan (policy) tidak selalu diikuti oleh perubahan dan perkembangan ditingkat implementasi pengajaran (Emilia, Hermawan \& Tati, 2008, Direktorat Akademik Direktorat Jenderal DIKTI, 2008) sehingga terjadi ketimpangan antara kebijakan dengan implementasinya. Penelitian yang dilaporkan pada artikel ini secara khusus mengkaji kurikulum pada mata kuliah Bahasa Inggris yang ditempatkan pada kurikulum di salah satu program studi di Politeknik Negeri Jember. Secara institusional, mata kuliah bahasa Inggris dianggap sebagai mata kuliah yang diperlukan di berbagai program studi di Politeknik Negeri Jember sehingga kurikulum pada semua program studi memasukkan mata kuliah Bahasa Inggris dengan bobot sks mulai dari 2 sampai 6 sks. Namun belum pernah ada kajian atau studi yang membahas sejauh mana implementasi pengajaran pada mata kuliah-mata kuliah bahasa Inggris tersebut telah sesuai dengan keinginan kurikulum induknya. Maka permasalahan yang ingin dijawab melalui penelitian ini adalah: (1) sejauh mana arah, tujuan, dan kompetensi kurikulum induk terefleksi dalam perencanaan pengajaran pada mata kuliah Bahasa Inggris?, dan (2) sejauh mana mata kuliah Bahasa Inggris diimplementasikan sesuai dengan arah, tujuan dan kompetensi kurikulum induknya?

\section{Kajian Pustaka}

\subsection{Kurikulum Bahasa Inggris di Perguruan Tinggi}

Dalam konteks pendidikan tinggi, pengajaran bahasa Inggris sering diarahkan untuk tujuan-tujuan khusus (ESP) baik akademis maupun profesional (Paltridge \& Starfield, 2013). Hal ini karena kurikulum bahasa Inggris di perguruan tinggi bersifat unik sehingga berbeda dengan kurikulum bahasa Inggris di sekolah dasar dan menengah. Faktor yang membedakan terletak pada fakta bahwa perguruan tinggi merupakan tingkat pendidikan terakhir yang menghubungkan dunia pendidikan dengan dunia kerja/profesional. Dalam konteks sosio-budaya yang dinamis dan terus mengalami 
perubahan, memaknai kurikulum hanya berdasarkan standar relevansi saja tidak cukup. Untuk memperkuat struktur kurikulum yang membentuk stabilitas internal kurikulum tersebut, standar relevansi perlu dilengkapi dengan standar koherensi. Koherensi yang dimaksud adalah mengukur natur dari setiap elemen dan domain kurikulum dan menguji kesesuaian praktek dengan kebijakannya.

Kurikulum dalam hal ini lebih dari sekedar dokumen tertulis yang berisi daftar mata kuliah ataupun rencana pengajaran. Berdasarkan Kepmendiknas No. 232/U/2000, kurikulum pendidikan tinggi didefinisikan sebagai perencanaan dan pedoman untuk menyelenggarakan KBM di perguruan tinggi. Namun, definisi ini diinterpretasikan ulang oleh Direktorat Akademik Direktorat Jenderal DIKTI (2008) menjadi lebih akomodatif dengan kebutuhan jaman yang mencakup tidak hanya sebagai dokumen tertulis, melainkan sebagai kebijakan managemen, filosofi, patron atau pola pembelajaran, iklim yang terbentuk dari interaksi akademis, rujukan kualitas, dan ukuran keberhasilan. Bahkan kurikulum merupakan suatu bentuk pembelajaran yang nyata-nyata dilakukan (actual curriculum) (ibid). Maka kurikulum semakin berperan penting dalam implementasi program-program pendidikan di perguruan tinggi. Sehingga terminologi kurikulum itu sendiri dapat dipergunakan untuk merujuk suatu landasan filosofis, kebijakan kurikulum nasional, kurikulum institusional (tingkat perguruan tinggi), kurikulum fakultas atau program studi, atau kurikulum mata kuliah.

Relevan dengan konsep ini, Novawan (2013) menggabungkan definisi Print (1993) dan Wiles \& Bondi (2007) sebagai berikut:

"curriculum construes all the planned learning opportunities offered to learners by the educational institution that represents a set of desired goals or values that are activated through a development process and culminate in successful learning experiences for students" (p.12)

Definisi ini memberikan suatu penekanan pada pentingnya suatu proses yang terpadu dan saling berkaitan satu dengan yang lain yaitu antara perencanaan, implementasi pengajaran, dan evaluasi terhadap pengalaman mahasiswa (Flowerdew, 2013). Maka proses ini sangat mementingkan adanya standar 'koherensi'. Koherensi bermakna ada keterpaduan antara apa yang telah direncanakan (curriculum as written) dengan apa yang diimplementasikan melalui pengajaran (curriculum as taught) yang kemudian dikonfirmasi oleh pengalaman yang dirasakan mahasiswa dan melalui assessment (curriculum as experienced). Standar koherensi dalam pengembangan kurikulum ini tidak menghilangkan standar relevansi karena standar relevansi merupakan suatu standar yang membentuk standar 'koherensi'. Sebagaimana yang terlukis pada frase "all the planned learning opportunities", koherensi perlu diawali dengan input dan evidence yang cukup untuk menemukan apa yang relevan (need analysis). Selanjutnya, apa yang relevan ini diproses sedemikian rupa sampai diwujudkan kedalam bentuk perencanaan yang matang untuk ditawarkan kepada masyarakat dan selanjutnya diimplementasikan. Maka, apa yang dialami mahasiswa dalam proses belajar merupakan suatu konfirmasi terkait terpenuhi atau tidaknya standar relevansi. Oleh karena itu, koherensi kurikulum bermakna ada relevansi pada setiap domain atau elemen kurikulum.

\subsection{Konteks dan natur kurikulum}

Karakter kurikulum ESP tidak bisa dilepaskan dari konteks spesifik yang mengelilinginya. Forum-forum ilmiah dan literatur dibidang ELT (English Language 
Teaching) maupun ESP (English for Specific Purposes) akhir-akhir ini menunjukkan suatu awareness terhadap pokok bahasan kurikulum ELT/ESP yang dikaitkan dengan realita socio-budaya tertentu dan keberadaannya diantara kurikulum-kurikulum yang lain di berbagai disiplin (misalnya: TEFLIN International 2014, RELC Conference 2015, Asian ESP Journal, Journal of Language Education in Asia, dll). Perkembangan ini mencerminkan semakin pentingnya mengkaji kurikulum Bahasa Inggris yang dikaitkan dengan konteksnya maupun keterkaitannya dengan disiplin ilmu dan bidang-bidang yang lain (ESP). Hal ini sebenarnya telah diindikasikan oleh berbagai studi sehingga Belcher (2004:165), satu dekade yang lalu mengatakan: "A common litany of complaints includes the observation that texts used in ESP pedagogy are too far removed from the real-life contexts that learners aim for". Bhatia, Anthony, \& Noguchi (2011), Basturkmen (2010) dan kebanyakan literatur ESP meyakini bahwa pengajaran ESP harus menekankan pada fungsi komunikatif yang efektif ditengah-tengah konteks akademis maupun profesional. Dengan begitu, kurikulum ESP bisa menjadi relevan dengan tujuan mahasiswa yang mempelajarinya.

Stroupe (2013) berpendapat bahwa globalisasi yang melanda dunia dan internasionalisasi yang terjadi di berbagai perguruan tinggi di dunia, telah memberikan dampak yang sangat signifikan terhadap perkembangan pengajaran Bahasa Inggris. Globalisasi mendorong terjadinya integrasi ekonomi baik di Asia maupun di Eropa. Di Eropa globalisasi mendorong negara-negara yang masuk didalamnya untuk melakukan internasionalisasi dan membuat standarisasi sistem pendidikan tinggi dalam kerangka convergence dan comparability (Raisanen \& Fortanet-Gomez, 2008). Melalui Bologna Agreement, negara-negara tersebut menjadikan bahasa Inggris sebagai bahasa komunikasi disamping 2 bahasa Eropa lainnya. Sedangkan di Asia, negara-negara yang tergabung didalam ASEAN menyepakati untuk menjadikan bahasa Inggris sebagai bahasa resmi untuk berkomunikasi antar negara ASEAN (Kirkpatrick, 2010). Mobilitas internasional para akademisi dan profesional diberbagai bidang memberikan pengaruh signifikan terhadap perkembangan dan penyebaran bahasa Inggris. Bahasa Inggris yang berinteraksi dengan berbagai konteks sosio-budaya menyebabkan terbentuknya variasi Bahasa Inggris yang unik yang disebut dengan istilah World Englishes (Kirkpatrick, 2010).

\subsection{Kurikulum Bahasa Inggris dalam kerangka koherensi}

Salah satu kekurangan dari kajian tentang kurikulum ESP adalah sangat sedikitnya literatur dan penelitian yang meneliti keterkaitan antara kurikulum mata kuliah Bahasa Inggris dengan kurikulum induknya. Hampir semua literatur membahas ESP dalam konteks ESP itu sendiri yang terpisah dengan discipline-specific kurikulum induknya. Hal ini karena kebanyakan literatur dan penelitian memiliki setting kurikulum yang berbeda dengan apa yang diterapkan di pendidikan tinggi di Indonesia. Di Indonesia, kurikulum bersifat subject-based dan bukan modular. Dalam setting kurikulum modular, mata kuliah ESP tidak menjadi bagian dari kurikulum induk dan biasanya tidak memiliki kredit. Namun, dalam konteks subject-based, mata kuliah bahasa Inggris dimasukkan ke dalam kurikulum menjadi bagian integral dari kurikulum induk. Dalam konteks ini, evaluasi kurikulum pada mata kuliah ESP meliputi evaluasi terhadap kurikulum induknya dengan mempertimbangkan koherensinya. Jika implementasi kurikulum ESP koheren dengan kurikulum induknya, maka spesifikasi yang diajarkan telah sesuai dengan tujuan dan kompetensi pada kurikulum induk. Dalam 
evaluasi kurikulum, prosedur yang umum adalah menilai kurikulum berdasarkan framework curriculum as planned atau disebut juga official curriculum dan curriculum as received atau yang disebut actual curriculum (Kelly, 2009). Sedangkan studi lain melihat kurikulum dari 3 demensi yaitu curriculum as written, curriculum as taught, dan curriculum as experienced (seperti pada Novawan, 2013).

\section{Metode Penelitian}

\subsection{Metode dan pendekatan}

Penelitian ini didasari oleh konsep naturalistic inquiry (Lincoln and Guba, 1985) sebagaimana lazimnya ketika penelitian bertujuan untuk mengungkapkan suatu realita tanpa melakukan manipulasi (Patton, 2002). Untuk mengungkapkan realita ini, metode yang dipergunakan adalah case study yang diharapkan mampu menolong peneliti untuk melakukan penetrasi terhadap situasi yang diteliti secara mendalam (Yin, 2009; Flyvbjerg, 2006; Cohen et al., 2000). Metode yang dipergunakan adalah analisa dokumen, wawancara, dan focus group discussion. Analisa dokumen dilakukan dalam 2 wilayah: (1) analisa dokumen tertulis terkait kurikulum induk yang berisi arah dan tujuan, deskripsi kompetensi, pemetaan mata kuliah, dan profil lulusan, dan (2) dokumen implementasi pengajaran seperti silabi, laporan kuliah dan praktikum, bahan ajar yang dipergunakan, daftar nilai dan portofolio mahasiswa. Sedangkan wawancara dilakukan terhadap dosen pengampu mata kuliah Bahasa Inggris dengan pendekatan semistructured. Sedangkan, focus group discussion dilakukan terhadap mahasiswa untuk mendiskusikan perspektif mereka terkait dengan apa yang mereka rasakan dan alami selama mengikuti mata kuliah Bahasa Inggris.

\subsection{Metode analisa data}

Data-data yang terkumpul dianalisa dengan menggunakan metode Immersion/Crystallisation (I/C) (Borkan, 1999). Metode ini sangat relevan dengan metode dan pendekatan penelitian yang menggunakan framework interpretivist sebagaimana pada penelitian ini. Pada dasarnya metode ini memungkinkan peneliti untuk mengintegrasikan proses pengumpulan data dengan proses analisa data karena keduanya bukan merupakan prosedur yang linear melainkan iterative. Prosedur yang iterative ini meliputi kegiatan-kegiatan yang terkait satu dengan yang lain dan tumpang tindih, yaitu: reflexivity, describing, crystallisation during data organisation, immersion and illumination, explication, corroborating/legitimating dan representing the account.

\section{Hasil dan Pembahasan}

\subsection{Analisa curriculum as written}

Kurikulum induk pada dasarnya menargetkan lulusannya untuk menguasai konsep dan teori yang memampukan mereka melakukan pekerjaan profesional baik yang bersifat teknis, administratif maupun manajerial (sebagai staf, penyelia, pengusaha, dll). Kompetensi yang ditargetkan meliputi kompetensi khusus di bidang Computer Engineering yang meliputi kompetensi terkait dengan Komunikasi Data, Organisasi Komputer, Jaringan Komputer, Jaringan Nirkabel, Administrasi Sistem, dan 
Pemrograman. Diskripsi utama kurikulum induk secara eksplisit tidak menyebutkan adanya target tertentu terkait kompetensi komunikasi dalam bahasa Inggris. Mata kuliah bahasa Inggris dengan bobot 6 sks mencerminkan arah kompetensi umum dan khusus dengan kesinambungan yang lemah. Berdasarkan Basturkmen (2010), visi mata kuliah bahasa Inggris ini termasuk wide-angled ESP yang membuka interpretasi yang beragam terkait sejauh mana kurikulum mengarahkan kompetensi bahasa Inggris. Keterbukaan ini menyebabkan implementasi di tingkat mata kuliah juga sangat terbuka tergantung pada dosen.

\subsection{Analisa curriculum as taught}

\subsubsection{Karakteristik silabi}

Silabi yang dipergunakan untuk pengajaran memiliki tujuan yang bersifat umum dan tidak secara eksplisit dijabarkan kedalam setiap pertemuan. Hal ini mengimplikasikan bahwa dosen menghendaki untuk masuk kedalam spesifikasi pengajaran dengan target-target yang spesifik dan kaku melainkan menginginkan adanya fleksibilitas yang menyesuaikan dengan kondisi kelas dan mahasiswa yang diajar. Disamping itu, silabi mata kuliah Bahasa Inggris memenuhi karakteristik sebagai silabi yang integrated (Richards, 2001). Silabi ini secara macro menargetkan pengajaran bahasa berdasarkan topik-topik yang dianggap penting dan sesuai dengan situasi yang dihadapi mahasiswa (situational syllabus), misalnya: "The importance of English proficiency in a global workplace", "The best way to master English", "Factors influencing the English mastery", dan "Ways of vocabulary learning". Penentuan topiktopik ini juga mengimplikasikan pentingnya konteks dan strategi belajar bahasa Inggris yang dianggap relevan dengan kebutuhan mahasiswa. Sedangkan secara micro, silabi mengindikasikan bentuk-bentuk aktivitas belajar yang didasarkan pada fungsi-fungsi grammar tertentu (functional), misalnya: parts of speech, statement and question, dan tenses, yang diwujudkan melalui berbagai bentuk tasks yang melatih performance mahasiswa dalam fungsi-fungsi tertentu dan bersifat kontekstual dan project-based (taskbased). Secara keseluruhan, silabi ini adalah representasi konsep dan ideologi competence-based curriculum yang melihat proses pengajaran harus menekankan pada kebermaknaan proses belajar dengan penekanan pada pengembangan situasi dan konteks yang mendukung proses belajar otentik dalam kemandirian peran sosial mereka ditengah-tengah komunitas kerja, akademis, sosial dan kelompok belajar mereka.

\subsubsection{Diskors instruksional}

Diskors instruksional dalam pengajaran ini menunjukkan adanya aplikasi metode-metode yang mengoptimalkan proses belajar yang individualised, aktif, dan mandiri sesuai dengan Direktorat Akademik DIKTI (2008). Dosen biasa memulai pengajaran dengan presentasi selama 15-30 menit dan melanjutkan dengan aktivitas yang interaktif yang dianggap relevan dengan presentasi dosen. Karakter dari 4 aspek pedagogi yaitu selection, sequencing, pacing, dan criteria cenderung didominasi karakter weak-framing. Dengan menganalisa laporan kegiatan kuliah dan praktikum, dapat diketahui bahwa keterselesaian materi sesuai dengan silabi sebesar 50\%. Kesesuaian topik yang tertulis pada silabi dan realita pada attendance list hanya sebesar $60 \%$ saja. Lalu, dosen tidak secara eksplisit mengontrol aspek sequencing dalam penyampaian materi. Apa yang tertulis pada silabi cukup generic sehingga memberikan keleluasaan pada implementasi pedagogi. Sedangkan workbook yang telah didisain berurutan mulai 
dari Reading Zone, Grammar Focus, Words Power, Listening Zone, Speaking Zone and Writing Zone, hanya dipergunakan sesuai dengan kebutuhan dan tidak begitu berorientasi pada urutannya. Pada aspek pacing, dosen bersikap lunak terhadap sejauh mana mahasiswa harus menguasai target kompetensi sesuai silabi. Pada aspek kriteria dan evaluasi, dosen membuatnya eksplisit melalui workbook yang dilengkapi dengan strategi belajar bahasa Inggris dengan menggunakan smart-cycle (vocabulary-grammarskill). Mulai dari pemilihan tema dan pengurutan aspek-aspek skills yang didisain pada workbook mengikuti konsep smart-cycle. Maka, orientasi utama dari mata kuliah adalah memberikan input "authentic use of English" dan strategi belajar yang tepat sehingga mampu menerapkan secara mandiri dalam konteks mereka sendiri.

\subsubsection{Diskors regulatif}

Diskors regulatif melihat pedagogi dari sisi hubungan antara dosen dengan mahasiswa dan bagaimana setiap pihak didalam proses belajar-mengajar itu menampilkan karakter dan nilai-nilai yang mempengaruhi proses pedagogi. Proses belajar-mengajar dikelas berjalan cukup lambat jika dibandingkan dengan timeline yang direncanakan. Proses belajar terjadi dalam bentuk interaksi alami yang bersifat two-way communication dan divergent yang bertujuan mengembangkan motivasi intrinsik mahasiswa ketimbang mengajarkan materi. Sehingga aktivitas belajar didominasi oleh aktivitas kelompok yang bersifat exploratory dan kontekstual. Disamping itu, pengajaran dikelas tidak berorientasi pada keakuratan linguistic features yang dibahas, melainkan lebih kepada exchanges of experience antara dosen dan mahasiswa dan antar mahasiswa sendiri. Dosen berusaha menciptakan konteks belajar yang memungkinkan mahasiswa mengeksplorasi proses belajar mereka sendiri untuk menemukan "materi" ketimbang langsung mengajarkan "materi". Keinginan untuk mengembangkan metacognitive skills mahasiswa tercermin dalam konsep pengajaran "the how" dan bukan pengajaran "the what". Jika dosen mengajar "the how", mahasiswa akan belajar memiliki kemandirian didalam belajar sehingga mampu menemukan "the what" itu sendiri. Jika dosen mengajarkan "the what", maka mahasiswa hanya bisa mengetahui "the what" saja dan tidak mengembangkan kemampuan untuk belajar mandiri.

\subsection{Analisa curriculum as experienced}

\subsubsection{Persepsi mahasiswa terkait pengalaman belajar}

Secara umum, mahasiswa yang mengikuti fokus group discussion merasa bahwa proses belajar yang mereka alami tidak berdampak signifikan terhadap kemampuan praktis dalam Writing dan Speaking. Namun, ada pengakuan yang merata bahwa banyaknya explorasi dan praktek didalam kelompok-kelompok kecil, dapat meningkatkan rasa percaya diri. Indikator penting terlihat dari data-data terkait bagaimana mereka menanggapi pertanyaan-pertanyaan terkait dengan tujuan/motivasi, proses dan hasil belajar.

Terkait dengan tujuan dan motivasi, mayoritas partisipan menganggap mata kuliah bahasa Inggris diperlukan (87\%) sedangkan 13\% tidak tahu apakah perlu atau tidak. Lalu $100 \%$ partisipan yakin bahwa bahasa Inggris diperlukan untuk pekerjaan mereka setelah lulus. Dan 62\% diantaranya memiliki motivasi intrinsik yang lebih baik sehubungan dengan belajar bahasa Inggris. Berkaitan dengan proses belajar-mengajar di kelas, sebesar 58\% menilai metode yang digunakan dosen baik dan sesuai dengan materi. 
Mayoritas partisipan menganggap materi yang diajarkan relevan ditunjang dengan kegiatan belajar yang berbobot. Namun, ada feedback bahwa sebagian besar proses belajar yang ada diluar kelas tidak mendapatkan pengawasan yang cukup baik. Secara mayoritas (90\%), partisipan mengakui bahwa suasana kelas cukup sehat dan bisa memotivasi mereka untuk belajar bahasa Inggris. Sikap dosen yang sering bercanda dikelas dan pendekatannya yang personalised dan tidak kaku membuat suasana tidak terlalu menekan. Sebagian besar partisipan (mencapai 80\%) beranggapan dosen cukup menyenangkan dan ramah. Sedangkan, terkait dengan hasil belajar, lebih dari $70 \%$ partisipan merasakan peningkatan self-confidence dalam berbicara bahasa Inggris, namun tidak sampai $50 \%$ yang yakin bahwa proses itu memberikan dampak signifikan pada peningkatan kemampuan mereka.

\subsubsection{Realita penguasaan target kompetensi}

Realita penguasaan target kompetensi didasarkan dari hasil evaluasi dosen terhadap kemampuan mahasiswa melalui hasil middle term test yang berisi 3 bagian, Bagian A meminta mahasiswa untuk menulis kalimat sesuai dengan perintah yang diberikan, sedangkan Bagian B meminta mereka untuk menulis paragraph untuk menjawab pertanyaan yang diberikan, dan Bagian $\mathrm{C}$ adalah percakapan dalam bahasa Inggris. Dari ketiga bagian tersebut, dapat diketahui sejauh mana mahasiswa memiliki 3 jenis kompetensi yang diharapkan, yaitu konseptual, praktis dan profesional. Kompetensi tersebut dinilai berdasarkan grading system yang logis yang diterapkan oleh dosen, yaitu A (sangat baik), B (baik), C (cukup), dan D (kurang).

Kompetensi konseptual diukur berdasarkan jawaban Part B (writing task) dan Part C (speaking task) yang mencerminkan perspektif mereka berkaitan dengan penguasaan bahasa Inggris. Kompetensi konseptual terdiri dari pemahaman terkait dengan natur bahasa Inggris (berbobot 30\%), stategi belajar bahasa Inggris (35\%), kemanfaatan bahasa Inggris dalam dunia profesional (35)\%. Pada Tabel 4.3.2.A, sebagian besar mahasiswa di Kelas A dan B memiliki kompetensi konseptual yang SANGAT BAIK. Sedangkan pada Kelas C dan D, kompetensi konseptual mahasiswa didominasi oleh mereka yang berada pada kategori CUKUP.

Tabel 4.3.2.A Kompetensi konseptual

\begin{tabular}{lllll|l}
\hline Grade & Kelas A & Kelas B & Kelas C & Kelas D & Jumlah/\% \\
\hline A & 10 & 15 & 7 & 7 & $40 / 37,39 \%$ \\
\hline B & 9 & 5 & 7 & 9 & $30 / 28,03 \%$ \\
\hline C & 8 & 5 & 12 & 10 & $35 / 32,71 \%$ \\
\hline D & - & 1 & 1 & - & $2 / 1,87 \%$ \\
\hline Total & 27 & 27 & 27 & 26 & $107 / 100 \%$ \\
\hline
\end{tabular}

Kompetensi praktis dalam penelitian ini adalah kemampuan untuk menggunakan kata dan tata bahasa yang diwujudkan melalui bentuk-bentuk ekspresi yang dapat terrefleksi dari lembar jawaban mahasiswa pada Part A terkait dengan keakuratan penggunaan vocabulary, statement \& question, dan 6 mostly used tenses. Pada Tabel 4.3.2.B, ada kesamaan dari semua kelas (A, B, C, dan D) dimana posisi kemampuan praktis mereka berada pada grade BAIK (B) dengan jumlah total 55 dari 107 populasi yaitu $51,4 \%$. 
Tabel 4.3.2.B Kompetensi praktis

\begin{tabular}{lllll|l}
\hline Grade & Kelas A & Kelas B & Kelas C & Kelas D & Jumlah/\% \\
\hline A & 9 & 3 & - & 1 & $13 / 12,14 \%$ \\
\hline B & 17 & 14 & 13 & 11 & $55 / 51,4 \%$ \\
\hline C & 1 & 9 & 13 & 14 & $37 / 34,6 \%$ \\
\hline D & - & 1 & 1 & - & $2 / 1,87 \%$ \\
\hline Total & 27 & 27 & 27 & 26 & $107 / 100 \%$ \\
\hline
\end{tabular}

Kompetensi profesional adalah kombinasi antara kemampuan konseptual dan praktis yang diterapkan secara khusus untuk tujuan bekerja. Pada penelitian ini, penilaian dilakukan terhadap kemampuan writing pada Part B dan kemampuan speaking. Pada Part $\mathrm{B}$, mahasiswa diberikan writing task seperti yang telah dibahas pada Kompetensi konseptual, dan Part C mahasiswa diberikan speaking tasks, seperti performing a short conversation on an assigned topic dan interview. Komponen penilaian terdiri dari 3 hal yaitu task achievement (40\%), message accuracy (30\%), and fluency (30\%). Seperti pada Tabel 4.3.2.B, mayoritas populasi yaitu sebanyak 56,07\% berada pada grade KURANG (D).

Tabel 4.3.2.B Kompetensi profesional

\begin{tabular}{lllll|l}
\hline Grade & Kelas A & Kelas B & Kelas C & Kelas D & Jumlah/\% \\
\hline A & - & - & - & - & - \\
\hline B & 2 & - & - & - & $2 / 1,87 \%$ \\
\hline C & 15 & 14 & 6 & 10 & $45 / 42,06 \%$ \\
\hline D & 10 & 13 & 21 & 16 & $60 / 56,07 \%$ \\
\hline Total & 27 & 27 & 27 & 26 & $107 / 100 \%$ \\
\hline
\end{tabular}

\subsection{Koherensi antara kebijakan dan implementasi}

Sebagaimana pada analisa 4.1, 4.2, dan 4.3, ada koherensi antara kebijakan dengan implementasinya, dimana kebijakan kurikulum induk yang bersifat implisit dan terbuka menunjukkan adanya preference dari policy makers yang mengarah kepada identitas pendidikan yang bersifat egalitarian ketimbang utilitarian. Identitas ini diimplementasikan melalui pedagogi yang weakly-framed yang relevan dengan konsep egalitarian. Sedangkan, pengalaman mahasiswa mencerminkan relevansi dengan dirasakannya "kesulitan" sebagai akibat pengajaran yang implicit namun pada saat yang sama memberikan penilaian positif terhadap proses itu.

\section{Kesimpulan}

Berdasarkan data-data yang telah dikumpulkan dan dianalisa pada penelitian ini, kurikulum Bahasa Inggris mencerminkan konsep integration, dimana mata kuliah Bahasa Inggris dianggap sebagai bagian yang terintegrasi dengan kompetensi interpersonal dan softskills lainnya. Knowledge discourse pada kurikulum Bahasa Inggris lebih bersifat egalitarian yang lebih menekankan pada pentingnya kompetensi konseptual yang membentuk dan mendorong personal branding dalam diri mahasiswa. 
Karakter knowledge discourse yang seperti ini lebih mengutamakan proses pembelajaran yang interinsik sehingga tidak menerapkan metode yang sangat syllabus-driven yang menuntut ketercapaian materi atau yang bersifat ekstrinsik. Pengalaman mahasiswa menunjukkan bahwa ada kesan dilematik didalam diri mereka. Pada satu sisi mereka mengapresiasi proses belajar yang mereka alami, namun pada sisi lain mereka kurang merasakan dampak langsung dalam keterampilan bahasa seperti dalam hal writing dan speaking. Dalam konteks pembelajaran yang intrinsik, kemampuan afektif yang terbentuk merupakan modal penting untuk pengembangan mahasiswa. Karena kompetensi afektif ini membentuk kemandirian yang stabil sehingga mahasiswa dapat mengalami proses long-life learning tanpa batasan ruang kelas.

Berdasarkan hasil penelitian ini, maka beberapa implikasi yang perlu diperhatikan oleh policy maker dan dosen adalah: (1) diperlukannya framework kompetensi bahasa yang terstandar sebagai acuan implementasi pengajaran untuk menghindari interpretasi pedagogi yang divergent, (2) diperlukannya laboratorium CALL (Computer Assisted Language Learning) dengan akses internet untuk proses pembelajaran enquiry-based modern, dan (3) pentingnya kelas-kelas kecil untuk pembelajaran yang student-centred. Disamping itu, penelitian ini memiliki kelemahan sebagai konsekuensi dari pembatasan tujuan penelitian dan metode. Pertama, fokus penelitian pada koherensi internal kurikulum menyebabkan need analysis tidak menjangkau TSA (Target Situation Analysis). Kedua, framework yang dipergunakan tidak memungkinkan untuk melakukan analisa knowledge discourse secara mendalam, seperti dengan menggunakan Bloom's Taxonomy. Ketiga, obyektifitas hasil analisa data dengan metode $\mathrm{C} / \mathrm{I}$ sangat memungkinkan kesimpulan yang dipengaruhi oleh perspektif peneliti. Terakhir, penelitian ini hanya menggunakan sampel kelas Bahasa Inggris 1 sehingga tidak memungkinkan untuk mengetahui keterkaitan antara Bahasa Inggris 1 dengan Bahasa Inggris lainnya pada kurikulum induk.

\section{DAFTAR PUSTAKA}

Basturkmen, H. (2010) Developing Courses in English for Specific Purposes. Basingstoke, UK: Palgrave Macmillan

Belcher, D. D. (2004) Trends in teaching English for Specific Purposes. Annual Review of Applied Linguistics, 24, 165-186

Bhatia, V., Anthony, L., and Noguchi, J. (2011) ESP in the $21^{\text {st }}$ Century: ESP theory and application today. Proceeding of the JACET $50^{\text {th }}$.

Borkan, J. (1999) 'Immersion/Crystallisation' in Crabtree, B. F. and Miller, W. L. (eds.) Doing Qualitative Research. 2nd edn. Thousand Oaks: Sage Publications.

Cohen, L., Manion, L. and Morrison, K. (2000) Research Methods in Education. 5th edn. London: RoutledgeFalmer.

Direktorat Jenderal Pendidikan Tinggi (2010) Buku Pedoman Kerangka Kualifikasi Nasional Indonesia. Jakarta

Direktorat Akademik Direktorat Jenderal Pendidikan Tinggi (2008) Buku Panduan Pengembangan Kurikulum Berbasis Kompetensi Pendidikan Tinggi. Jakarta 
Dudley-Evans, T. and St. John, M. J. (1998) Developments in English for Specific Purposes: A multi-disciplinary approach. Cambridge: Cambridge University Press.

Flowerdew, L. (2013) Need Analysis and Curriculum Development in ESP. In Paltridge, B. and Starfield, S. (Eds) The Handbook of English for Specific Purposes. West Sussex: John Wiley and Sons.

Flyvbjerg, B. (2006) 'Five misunderstandings about Case-Study Research', Qualitative Inquiry, 12(2), pp. $219-245$.

Fortanet-Gomez, I. and Raisanen, C. A. (Eds) (2008) ESP in European Higher Education: Integrating language and content. Amsterdam: John Benjamins Publishing Company

Hyland, K. (2006) English for Academic Purposes: an advance resource book. London: Routledge.

Kementerian Pendidikan dan Kebudayaan (2012) Pedoman Pengembangan Kurikulum 2013. Jakarta

Kelly, A.V. (2009) The Curriculum: Theory and Practice. 6th edn. London: Sage Publications.

Kirkpatrick, A. (2010) English as an Asia Lingua Franca and the Multilingual Model of ELT. Language Teaching, 1-13

Kuzel, A. J. (1999) 'Sampling in Qualitative Inquiry' in Crabtree, B. F. and Miller, W. L. (eds.) Doing Qualitative Research. 2nd edn. Thousand Oaks: Sage Publications.

Lincoln, Y. S. and Guba, E. G. (1985) Naturalistic Inquiry. Newbury Park, California: Sage Publications

Long, M. (2005) Methodological issues in learner needs analysis. In Long, M. (ed.) Second Language Needs Analysis. 19-76. Cambridge: Cambridge University Press.

Novawan, A. (2013) A case study of curriculum and pedagogic discourse of English Professional Communication in a Higher Education Institution in the United Kingdom. Dissertation of Master's Degree in Education. Newcastle, UK: Newcastle University.

Nunan, D. (2004) Task-based Language Teaching. Cambridge: Cambridge University Press.

Paltridge, B. and Starfield, S. (2013) The Handbook of English for Specific Purposes. West Sussex: John Wiley and Sons.

Patton, M. Q. (2002) Qualitative Research and Evaluation Methods. 3rd edn. Thousand Oaks: Sage Publications.

Print, M. (1993) Curriculum Development and Design. 2nd edn. NSW: Allen and Unwin.

Stroupe, R. (2013) The language educator and globalization: How do we best prepare our learners? Language Education in Asia, 4(2), 110-121

Wiles, J. and Bondi, J. (2007) Curriculum development: A guide to practice. 7 th edn. Upper Saddle River, NJ: Prentice Hall.

Yin, R.K. (2009) Case Study Research: Design and Methods. 4th edn. Thousand Oaks: Sage Publication. 